\title{
Pengaruh ASEAN Disability Forum Terhadap Pengembangan Ekonomi Penyandang Disabilitas di Indonesia
}

\author{
Demeiati Nur Kusumaningrum, Olivia Afina, Riska Amalia Agustin, dan \\ Mega Herwiandini ${ }^{1}$
}

\begin{abstract}
Disabilities is a person who has a physical defect that affects their activity in society. Their problems like as discrimination, social imbalance, less of infrastructur, and the lack of employment opportunities is the assignment of the government to completion of that injustice. Indonesian became one of the country that haven't be able to solve the problems of disability. It's also be a serious discussion in ASEAN. So, in 2011 the ASEAN leaders agreed on the establishment of ASEAN Disability Forum as a container to accommodate the aspirations of ther disabilities in order to their justice. ASEAN Disability Forum expected to solve the problems of disability in other ASEAN countries, especially in Indonesia. The main problem is expected to be resolved is employment opportunities for the disabled so as to improve their lives.
\end{abstract}

Keywords: Disabilities, ASEAN Disabiliy Forum, Indonesian

\begin{abstract}
Abstrak
Penyandang disabilitas merupakan seseorang yang memiliki keterbatasan fisik sehingga mempengaruhi segala aktivitasnya di masyarakat. Permasalahan mereka seperti diskriminasi, ketimpangan sosial, keterbatasan infrastruktur, serta minim nya peluang kerja menjadi tugas pemerintah dalam penyelesaian ketidakadilan tersebut. Indonesia menjadi salah satu negara yang masih belum mampu menangani permasalahan penyandang disabilitas. Hal ini juga menjadi pembahasan serius di ASEAN. Sehingga, pada tahun 2011 para pemimpin ASEAN menyepakati dibentuknya ASEAN Disability Forum sebagai bentuk wadah untuk menampung aspirasi para disabilitas agar memperoleh keadilan mereka. ASEAN Disability Forum diharapkan mampu menyelesaikan permasalahan para disabilitas di negara ASEAN, terutama di Indonesia. Permasalahan utama yang diharapkan bisa terselesaikan yaitu kesempatan kerja bagi para penyandang disabilitas sehingga mampu meningkatan taraf hidup mereka.
\end{abstract}

Kata-kata Kunci : Disabilitas, ASEAN Disability Forum, Indonesia

\section{Pendahuluan}

Sebagai manusia, dalam kehidupannya tidaklah ada yang sempurna. Segala kekurangan manusia didapat dari maupun dengan cara yang berbeda-beda. Di Indonesia, masyarakat yang harus diperhatikan oleh negara maupun masyarakat sekitar salah satunya adalah para penyandang disabilitas. Menurut Undang-Undang Indonesia Nomor 8 Tahun 2016 tentang penyandang Disabilitas Pasal 1 menyatakan bahwa penyandang disabilitas adalah setiap orang yang mengalami keterbatasan fisik, intelektual, mental dan/atau sensorik dalam jangka waktu lama yang dalam berinteraksi dengan lingkungan dapat mengalami hambatan dan kesulitan untuk berpartisipasi secara penuh dan efektif dengan warga negara lainnya berdasarkan kesamaan hak.

Permasalahan hidup penyandang disabilitas tergolong serius di berbagai negara. Terkadang mereka mengalami diskriminasi di masyarakat hingga akhirnya tidak memperoleh hak-hak yang seharusnya mereka dapat.

\footnotetext{
${ }^{1}$ Para peneliti Laboratorium Hubungan Internasional UMM pada Center for Intermestic Studies (CIS)
} 
Oleh karena itu, pada tahun 2006 PBB mengesahkan Konvensi tentang hak penyadang disabilitas (Convention on The Rights of Persons with Dissabilities) (Riyadi dkk, 2012). Hal ini dilakukan untuk mengurangi dan melindungi hak-hak penyandang disabilitas karena segala bentuk kejahatan kepada para penyandang disabilitas dianggap sebuah kejahatan kemanusiaan. Maka, PBB membuat konvensi tersebut agar dapat diterima oleh negara-negara serta mampu mengurangi permasalahan yang terjadi pada para penyandang disabilitas.

ASEAN juga ikutserta dalam melakukan perlindungan terhadap para penyandang disabilitas. Para perwakilan negara ASEAN menganggap bahwa permasalahan penyandang disabilitas cukup mengkhawatirkan dan diperlukan sebuah perlindungan terhadap aspirasi hak mereka. ASEAN Disability Forum (ADF) menjadi forum bagi negara-negara ASEAN untuk mendukung perlindungan terhadap penyandang disabilitas. Cikal bakal terbentuknya ADF yaitu pada tahun 2009 ketika perwakilan Disable People's Organisations (DPOS) menghadiri ASEAN People's Forum (APF) untuk mempromosikan serta menyadarkan tentang hak-hak penyandang disabilitas yang harus dilindungi. Sedangkan pada tahun 2011 pada penyelenggaraan KTT ASEAN ke-19 di Bali, para pemimpin ASEAN mengesahkan Bali Declaration in Enhancing the Role on
Participation of Persons with Disabilities in ASEAN Community (Kementerian Luar Negeri, $2016: 44$ )

Pembentukan Forum Disabilitas ASEAN bertujuan untuk mewakili aspirasiaspirasi dari penyandang disabilitas di seluruh negara ASEAN. Selain iu, dengan dibentuknya ADF maka membuka peluang kesempatan bagi para penyadang disabilitas untuk turut serta dalam masyarakat ASEAN. ADF juga melakukan berbagai kerjasama dengan berbagai LSM, pebinsis, pemerintah, media dan segala bentuk partisipasi untuk mendukung terlaksana nya perlindungan bagi penyandang disabilitas.

Indonesia juga menjadi salah satu negara Asia tenggara yang mendukung dibentuknya ADF tersebut. Mengingat bahwa Indonesia merupakan negara di Asia Tenggara yang memiliki populasi masyarakat penyandang disabilitas sekitar $10 \%$ dari populasi penduduk di Indonesia (ILO : 2). Melalui ADF, Indonesia mengharapkan perkembangan kesejahteraan bagi penyandang disabilitas agar terbuka ruang-ruang pekerjaan serta partisipasi aktif para penyandang disabilitas terhadap negara. Selain itu, melalui ADF negara-negara ASEAN mampu memfokuskan kebijakan-kebijakan pemerintah terhadap para penyandang disabilitas.

Penelitian ini bertujuan untuk mengetahui potensi terbentuknya ADF terhadap kebijakan pemerintah sehingga mampu memperbaiki kesejahteraan dan 
peluang pekerjaan bagi penyandang disabilitas di Indonesia sehingga dapat memberikan kesempatan yang sama untuk meningkatkan kesejahteraan perekonomian para penyandang disabilitas tersebut. Dengan demikian, bagaimana pengaruh dibentuknya $A S E A N$ Disability Forum terhadap kebijakan pemerintah dan peluang kerja bagi penyandang disabilitas di Indonesia menarik untuk dianalisis.

\section{Pendekatan Intermestik dalam Studi} Hubungan Internasional

Tulisan ini menggunakan pendekatan domestik dalam mengkaji proses perubahan kebijakan yang menaruh perhatian pada aktor dan motivasi kepentingan aktor-aktor domestik terhadap perubahan kebijakan. Dalam pendekatan internasional, proses perubahan kebijakan dilihat sebagai kepentingan aktoraktor internasional yang menginginkan perubahan kebijakan baik dengan cara menekan ataupun menyediakan preferensipreferensi yang bisa dipilih secara sukarela oleh negara. Berbeda dengan keduanya, pendekatan transnasional tidak menganggap kepentingan sebagai faktor yang penting tetapi justru ide, pengetahuan, ataupun discourse yang bisa melibatkan aktor-ktor lintas batas negara (Kurniawati, 2012).

Menurut Kurniawati (2012) dalam "Pendekatan Intermestik Dalam Proses Perubahan Kebijakan: Sebuah Review Metodologis", peran ide dan kepentingan dari para aktor domestik maupun internasional sama-sama penting dalam proses perubahan kebijakan model intermestik. Peran ide sangat berpengaruh dalam proses yang meliputi penyaringan awal alternatif kebijakan yang didasari oleh transmisi pengetahuan dari jaringan intelektual, kemudian perdebatan ide diantara koalisi advokasi mengasilkan proses learning yang mengarah pada konsensus. Sedangkan peran kepentingan aktor sangat berpengaruh dalam proses politik, yaitu kompetisi diantara para koalisi advokasi dengan tujuan untuk mengarahkan keputusan agar sesuai dengan kepentingannya, yang didasari oleh konsensus ide/keyakinan yang dimilikinya. Dengan demikian dalam pendekatan intermestik faktor ide dan kepentingan aktor menjadi sama-sama penting. Hal inilah yang membedakan pendekatan/ model intermestik dengan model-model teori lainnya, karena sebagian memahami perubahan kebijakan hanya sebagai proses perjuangan kepentingan aktor domestik atau internasional saja, dan sebagian yang lain memahami perubahan kebijakan sebagai proses transmisi ide/pengetahuan sehingga kalaulah terjadi perubahan kebijakan domestik pasti melibatkan interaksi transnasional.

Istilah "intermestik" -singkatan dari internasional dan domestik- bukan merupakan sebuah aliran pemikiran (school of thought). Intermestik adalah pendekatan yang berupaya menggambarkan interaksi atau keterkaitan antara isu-isu internasional dan domestik, yang berdampak pada fenomena (issue), kebijakan 
Demeiati Nur Kusumaningrum, Olivia Afina,

Riska Amalia Agustin, dan Mega Herwiandini

(policy), dan gagasan/nilai (idea, norm, value). Istilah "intermestic" kali pertama digunakan Henry Kissinger untuk menjelaskan tentang isu-isu internasional yang berimplikasi terhadap ekonomi nasional Amerika Serikat (AS). Hal tersebut dicontohkan dengan instabilitas politik di Timur-Tengah yang mempengaruhi harga minyak dunia, terutama pasar AS. Di Indonesia, istilah intermestik dipopulerkan pada tahun 2002 oleh mantan Menteri Luar Negeri, Hasan Wirayuda yang memandang adanya keterkaitan antara isu internasional terhadap kebijakan-kebijakan di dalam negeri. Sehingga, baik Kissinger dan Wirayuda, menggunakan pendekatan intermestik untuk menganalisis politik luar negeri (Kusumaningrum \& Kurniawati, 2016).

Dalam mengkaji fenomena domestik (isu, proses kebijakan, maupun ide/norma), selama ini yang sering digunakan adalah pendekatan domestik dan pendekatan internasional. Pendekatan domestik berasumsi bahwa fenomena domestik dipengaruhi oleh peran aktor-aktor domestik seperti pemimpin negara yang perilakunya dapat merepresentasikan kepentingan individunya maupun kepentingan nasional. Di samping itu juga dapat dipengaruhi oleh birokrat, parlemen, dan kelompok kepentingan (iron triangle), koalisi advokasi yang disatukan oleh persamaan belief system? (Sabatier \& JenkinsSmith, 1993), maupun sistem organisasional yang bersifat mekanis (Easton, dalam Mas'oed, 1984).
Sebaliknya, dalam pendekatan internasional fenomena domestik seringkali dilihat sebagai sebuah agenda internasional yang terjadi karena adanya penyediaan preferensi-preferensi yang dipilih baik secara sukarela maupun paksaan. Oleh karena itu dalam pendekatan internasional peran aktoraktor domestik justru tidak sepenuhnya dominan. Untuk memisahkan antara fenomena domestik maupun internasional di era globalisasi sangatlah sulit karena keduanya saling terkait. Penyebaran isu, proses kebijakan, maupun diseminasi ide/norma domestik pun terbentuk dalam konteks adanya keterkaitan dengan lingkungan global sehingga dibutuhkan sebuah pendekatan yang bisa menjembataninya (bridging the gab). Pendekatan ini disebut intermestik (Kurniawati, 2012).

Transnasionalisme menggambarkan semakin beragamnya aktor baik lokal, nasional, maupun internasional yang dapat membentuk jaringan secara transnasional, juga beragamnya isu yang berpengaruh dalam proses pembuatan kebijakan negara, seperti eonomi, politik, sosial, budaya, dll (Peterson, 1992). Studi kebijakan menjadi tidak hanya menggambarkan tentang rasionalitas pembuat kebijakan, namun juga proses networking dan learning yang dilakukan oleh para aktor pembuat kebijakan dengan aktor-aktor lain secara lintas batas negara sehingga konsepkonsep seperti epistemic community (Haas, 1994), transnational advocacy network (Keck 
\& Sikkink, 1999), dan lain-lain banyak digunakan. Di sinilah pendekatan intermestik diperlukan dimana proses kebijakan melibatkan interaksi antara aktor-aktor tidak hanya domestik tetapi juga internasional. Prosesnya pun tidak hanya proses politik yang mengedepankan faktor kepentingan, namun juga proses learning terhadap suatu ide/wacana kebijakan yang tidak mengenal batas negara. Dengan demikian, pendekatan intermestik digunakan untuk menggambarkan pengaruh kesepakatan ASEAN terhadap permasalahan disabilitas di Indonesia.

\section{Metode}

Dalam menganalisis isu ini, penulis menggunakan metode penelitian kualitatif untuk memastikan apakah dengan adanya ASEAN Disability Forum mampu menampung aspirasi para penyandang disabilitas salah satunya di Indonesia. Dalam menentukan proses pencarian, penelitian, dan pengolahan data yang digunakan dalam riset ini, penulis menggunakan teknik analisis data deduksi. Teknik analisis data deduktif yakni dimana penulis memulai pembahasan dengan menggambarkan masalah secara umum, lalu kemudian memaparkan secara khusus pengaruh dari masalah yang terlebih dahulu digambarkan.

Teknik pengumpulan data yang digunakan adalah telaah pustaka atau library research, yaitu cara pengumpulan data teoritis dengan menelaah sejumlah literatur yang berhubungan dengan masalah yang diteliti baik berupa buku, jurnal, dokumen, makalah, laporan dan artikel yang berhubungan dengan masalah ini. Data yang nantinya akan diperoleh ini yang akan dianalisis dan diolah untuk menjawab permasalahan dalam penelitian.

Dalam penelitian ini hanya akan dijabarkan tentang tujuan dibentuknya $A S E A N$ Disability Forum (ADF) serta fungsinya di ASEAN. Selain itu, juga akan dijelaskan tenang perlindungan pemerintah Indonesia terhadap penyandang disabilitas dan kesempatan para penyadang disabilitas untuk mendapatkan peluang pekerjaan di berbagai bidang.

\section{Penyandang Disabilitas di Indonesia}

Penyandang disabilitas merupakan kelompok minoritas terbesar di dunia dimana populasinya sekitar $15 \%$ dari seluruh penduduk didunia. Sekitar $82 \%$ penyandang disabilitas berada di negara miskin dan berkembang dengan taraf hidup berada dibawah garis kemiskinan dan seringkali memiliki keterbatasan dalam memperoleh akses kesehatan, pendidikan, maupun pekerjaan yang layak (ILO : 1) serta sulitnya akses transportasi dan pembangunan sehingga menjadi penghambat dalam aktivitas penyandang disabilitas (Better Work Indonesia, 2013:3). Walaupun telah disepakati Undang Undang Internasional tentang Hak Asasi Manusia, namun hak tersebut masih 
Demeiati Nur Kusumaningrum, Olivia Afina,

Riska Amalia Agustin, dan Mega Herwiandini

sering kali tidak didapatkan oleh penyandang disabilitas. Mereka merupakan kelompok yang rentan terhadap diskriminasi maupun ketidakadilan di berbagai negara di dunia (Harahap dan Bustanuddin, 2015:18).

Menurut KBBI sendiri kata "penyandang" berartikan seseorang yang sedang mengalami atau memiliki sesuatu, dan "disabilitas" merupakan kata serapan asing dari “disability/disabilities(jamak)”(KBBI, 2008). Sementara dalam Undang-Undang Republik Indonesia Nomor 8 Tahun 2016 Tentang Penyandang Disabilitas, disebutkan bahwa "Penyandang Disabilitas adalah setiap orang yang mengalami keterbatasan fisik, intelektual, mental, dan/atau sensorik dalam jangka waktu lama yang dalam berinteraksi dengan lingkungan dapat mengalami hambatan dan kesulitan untuk berpartisipasi secara penuh dan efektif dengan warga negara lainnya berdasarkan kesamaan hak".

Dikutip dari portal berita online news.okezone.com yang dimuat Kamis 3 Desember 2015, pada berita tentang penyadang disabilitas Indonesia yang mencapai 9 juta jiwa dalam berita tersebut dikatakan bahwa Berdasarkan data dari Badan Pusat Statistik (BPS) Republik Indonesia, pada 2010 tercatat jumlah penyandang disabilitas mencapai sekira 9.046.000 jiwa dari sekira 237 juta jiwa. Cacat melihat kategori ringan sebanyak 5.313 jiwa dan parah sebanyak 507 jiwa. Cacat mendengar kategori ringan sebanyak 5.268 jiwa, sementara kategori parah
456 jiwa. Untuk disabilitas yang kesulitan berjalan atau menaiki tangga dalam kategori ringan berjumlah 2.432 jiwa sementara kategori parah sebanyak 656 jiwa. Penyandang cacat yang kesulitan mengingat atau konsentrasi, termasuk seperti autis atau down syndrome, kategori ringan sebanyak 2.126 jiwa sementara kategori berat sebanyak 616 jiwa. Penyandang cacat yang kesulitan mengurus diri sendiri dalam kategori ringan sebanyak 1.511 jiwa sedangkan kategori parah berjumlah 533 jiwa. Dasar pendataan terhadap kaum disabilitas diatas, dibatasi dari usia 10 tahun ke atas, karena di usia tersebut masyarakat dinilai sudah bisa mengidentifikasi dirinya sendiri.

Maksud dari pemaparan data tersebut adalah, ternyata cukup banyak penyandang disabilitas yang ada di Indonesia, dan tentunya jika penyandang disabilitas memiliki pekerjaan maka pertumbuhan ekonomi di Indonesia pun dapat meningkat, begitu pula sebaliknya. Kepedulian terhadap kaum disabilitas di Indonesia sampai saat ini pun masih dalam perjuangan, akan tetapi pada masa sekarang ini sudah banyak titik cerah bagi kaum disabilitas, seperti adanya undang-undang bagi penyandang disabilitas UU no. 8 tahun 2016, mempertegas adanya eksistensi dari penyandang disabilitas di sekitar kita, dan memperjelas hak-haknya, seperti yang tertulis pada Pasal 5 Ayat (1) Undang-Undang Republik Indonesia Nomor 8 Tahun 2016 Tentang Penyandang Disabilitas, menyebutkan 
bahwa Penyandang Disabilitas memiliki hak sebagai berikut: a.) hidup; b.) bebas dari stigma; c.) privasi; d.) keadilan dan perlindungan hukum; e.) pendidikan; f.) pekerjaan, kewirausahaan, dan koperasi; g.) kesehatan; h.) politik; i.) keagamaan; j.) keolahragaan; k.) kebudayaan dan pariwisata; 1.) kesejahteraan sosial; m.) Aksesibilitas; n.) Pelayanan Publik; o.) Pelindungan dari bencana; p.) habilitasi dan rehabilitasi; q.) Konsesi; r.) pendataan; s.) hidup secara mandiri dan dilibatkan dalam masyarakat; dan t.) berekspresi ( UU No.8, 2016).

Perhatian terhadap penyandang disabilitas di Indonesia tentunya semakin baik karena banyaknya dorongan dan dukungan dari organisasi disabilitas seperti PPDI (Persatuan Penyandang Disabilitas Indonesia), GPDLI (Gerakan Peduli Disabilitas dan Lepra Indonesia), HWDI (Himpunan Wanita Disabilitas Indonesia), dan lainnya. Rencana kedepannya organisasi-oraginasi tersebut akan membentuk Komnas Disabilitas Indonesia yang bertujuan sebagai badan yang memiliki advokasi dan mampu menangani permasalahan -permasalahan yang dialami penyandang disabilitas. Selain dalam Negri, dalam konteks Kawasan Asia Tenggara, ASEAN juga memiliki lembaga atau forum yang mendukung penyandang disabilitas yakni ASEAN Disability Forum.

\section{ASEAN Disabilty Forum}

Hak Asasi Manusia merupakan segala bentuk hak-hak yang dimiliki oleh seseorang sejak ia lahir dan hak tersebut dilindungi oleh negara. Hak Asasi Manusia dijadikan sebagai wadah untuk melindungi seseorang dari ancaman di negara serta menjamin kehidupan kesejahteraan mereka. Sebenarnya, konsep Hak Asasi Manusia telah diterapkan sejak zaman dahulu. Kebebasan serta perlindungan seseorang telah banyak dilakukan oleh lingkungan masyarakat. Namun, hal itu mulai dikembangkan dengan adanya perjanjian ataupun Undang-Undang negara yang ditulis secara formal.

Perjanjian pertama yang mendasari adanya perlindungan terhadap HAM yaitu Magna Carta pada tahun 1215, dimana dalam naskah tersebut Raja John dari Britania Raya (Inggris) memberikan hak-hak kepada beberapa bangsawan bawahannya atas tuntutan mereka dan dengan itu maka membatasi kekuasaan Raja Jhon. Sejalan dengan perkembngannya, maka perlindungan terhadap HAM yang paling universal dan menjadi landasan bagi negara-negara untuk menerapkan kebijakan tentang HAM yaitu Universal Declaration of Human Rights pada tahun 1948. Deklarasi tersebut dibentuk oleh PBB untuk melindungi Hak-Hak Asasi Manusia di seluruh dunia yang harus dihormati oleh warga negara (Mardenis, 2013:443)

Indonesia menjadi salah satu negara yang juga meratifikasi kebijakan mengenai perlindungan Hak Asasi Manusia. Hal itu didasari oleh Indonesia sebagai langkah dalam 
Demeiati Nur Kusumaningrum, Olivia Afina,

Riska Amalia Agustin, dan Mega Herwiandini

mendukung dan bertanggungjawab sebagai anggota PBB serta masih banyaknya pelanggaran HAM yang terjadi di Indonesia. Langkah yang dilakukan oleh Indonesia yaitu dengan membentuk Undang-Undang Indonesia tentang Hak Asasi Manusia. Dalam Pasal 281 ayat 4 UUD 1945 dijelaskan bahwa perlindungan, pemajuan, penegakan, dan pemenuhan HAM adalah tanggungjawab negara, terutama pemerintah (Komnas HAM, 2016:8). Dalam rancangan Undang-Undang tahun 2016 Tentang Hak Asasi Manusia juga disebutkan dalam Hak-Hak Dasar pasal 2 yang menyaakan bahwa negara Indonesia mengakui dan menjunjung tinggi Hak Asasi Manusia dan kebebasan dasar manusia sebagai hak yang tidak dapat dipisahkan dari hidup manusia, yang harus dilindungi, dihormati dan ditegakkan demi mengkatkan kesejahteraan, martabat kemanusiaan, kebahagiaan, kecerdasan serta keadilan (Komnas HAM, 2016:3). Oleh karena iu, negara bertanggungjawab penuh terhadap penegakan HAM masyarakat Indonesia salah satunya adalah hak para penyandang disabilitas.

Dikutip dari portal resmi ASEAN Disability Forum Asean Disability Forum. (ADF) merupakan jaringan yang beranggotakan DPOs dari kawasan ASEAN. Dimana DPOs disini merupakan koordinator tindakan untuk mengadvokasi perumusan inklusif kedisabilitas dan implementasi. perumusan kebijakan inklusif kedisabilitasan dan implementasi. ADF memiliki melingkupi dalam semua bidang, dan bertujuan untuk membantu kebutuhan penyandang disabilitas dan memasukkan perspektif mereka dalam kerangka kebijakan ASEAN.

ADF mempunyai tujuan utama yaitu partisipasi penuh dan pemerataan kesempatan penyandang disabilitas dalam masyarakat ASEAN. Selain itu ADF memainkan banyak dengan memfasilitasi saling berbagi informasi. Selain itu, ADF memainkan banyak peran di tingkat lokal, nasional, dan internasional untuk penyandang disabilitas, berkerja sama dengan pemerintah, penyedia layanan dan masyarakat umum. Dalam banyak kasus, ADF adalah kendaraan terbaik dalam melaksanakan aspirasi penyandang disabilitas. Sebelum komunitas ASEAN; ADF merupakan sebuah platform tindakan untuk membawa suara DPOs di tingkat akar rumput untuk pembuat kebijakan dan menghubungkan orang- orang pembuat kebijakan untuk orang yang hidup di negara-negara anggotanya.

Inisiatif ADF dimulai pada tahun 2009, ketika sekelompok DPOs menghadiri Forum Rakyat ASEAN (APF), menyadari bahwa untuk meningkatkan kesadaran tentang hakhak penyandang disabilitas dan mempromosikan adopsi kedisabilitasan kebijakan inklusif dalam negara-negara ASEAN, DPOs dibutuhkan untuk mengatur dan membangun kapasitas advokasi untuk mempengaruhi struktur ASEAN. Untuk memulai DPOs menjadi anggota Panitia Nasional APF, erat terlibat dengan Organisasi 
Masyarakat Sipil ASEAN lainnya; ini memungkinkan mereka untuk memperkenalkan sesi permanen pada hak-hak penyandang disabilitas di APF yang termasuk dalam Pernyataan akhir dari Forum yang kemudian diserahkan kepada KTT ASEAN.

Peresmian Forum Disabilitas ASEAN dilakukan pada 18-19 September 2011, di Bangkok, Thailand. Dalam kesempatan itu, ADF mengadopsi Deklarasi Bangkok, yang memberikan masukan untuk mempromosikan disabilitas kebijakan inklusif, dalam Kerangka Strategis Kesejahteraan Sosial dan Pembangunan 2011-2015 (sebagai bagian dari Dekade ASEAN PWD 2011-2020). ADF saat ini terdiri oleh 10 DPOs dari Brunei, Kamboja, Myanmar, Indonesia, Lao PDR, Malaysia, Filipina, Singapura, Vietnam dan Thailand. Para anggota ADF (Annex 1) pada tingkat negara akan mewakili ADF dan kerja kolaboratif dengan pemerintah, DPOs, CSO, Bisnis, Media dan organisasi terkait lainnya untuk melaksanakan kegiatan meliputi advokasi dan lobi kerja dan menginformasikan ke dan bekerja berdampingan dengan ADF sekretariat Jakarta.

\section{Pengaruh ADF di Indonesia}

Menurut hasil laporan Adioetoemo dkk dari FE UI, permasalahan disabilitas di berbagai sektor menjadi hal penting yang harus diselesaikan oleh pemerintah Indonesia. Keterbatasan para penyandang disabilitas di lingkungannya akan berdampak terhadap minimnya partisipasi para penyandang disabilitas, misalnya dalam hal pengembangan di sektor sosial ekonomi. Minimya lahan pekerjaan dan diskriminasi di dunia kerja yang diterima oleh para penyandang disabilitas merupakan hal riil yang sering terjadi di masyarakat. Hal itu dapat beresiko terhadap tingginya angka kemiskinan bagi penyandang disabilitas.

Penyandang disabilitas sebenarnya memiliki potensi untuk bekerja seperti kebanyakan orang lainnya. Dalam dunia kerja, biasanya mereka memiliki kemauan yang tinggi dalam mempertahankan pekerjaannya serta mampu berproduktifitas lebih baik. Apabila ada kesempatan kerja, penyandang disabilitas tidak akan ragu untuk menunjukkan keahlian dan bakat mereka yang belum dimanfaatkan. Pemanfaatan penyandang disabilitas di dunia kerja mampu meningkatkan keberagaman, kreativitas, rasa saling menghargai, serta mampu meningkatkan reputasi perusahaan dikalangan masyarakat (Better Work Indonesia, 2013 : 5). Hal ini juga telah diatur dalam Undang Undang No.4 tahun 1997 mengenai penyandang disabilitas dan Peraturan Pemerintah No.43 tahun 1998 (Better Work Indonesia, 2013 : 4) mengenai upaya meningkatkan kesejahteraan sosial bagi penyandang disabilitas (ILO : 3 ).

Akan tetapi, kesempatan kerja tersebut masih sangat minim karena masih adanya ketimpangan sosial dimasyarakat dalam menerima para penyandang disabilitas. Mereka dianggap kurang mampu dalam menjalankan 
suatu pekerjaan karena keterbatasan yang mereka miliki. Bahkan, pemerintah Indonesia juga masih belum mampu dalam menangani masalah pekerjaan bagi penyandang disabilitas. Hal ini, tidak hanya terjadi di Indonesia, tetapi masalah ini juga menjadi pembahasan regional di Asia tenggara. Oleh karena itu, para pemerintah Asia Tenggara melalui ASEAN sepakat untuk mengadopsi kebijakan Internasional dalam menangani masalah penyandang disabilitas melalui adanya $A S E A N$ Disability Forum.

Menurut Maulani A. Rotinsulu, ketua Himpunan Wanita Disabilitas Indonesia (HDWI) dan merupakan salah satu pengurus Forum Disabilitas ASEAN megatakan bahwa ketidakpedulian terhadap para penyandang disabilitas oleh masyarakat dikarenakan ketidakpahaman mereka. Mereka hanya melihat penyandang disabilitas dengan sebelah mata, tanpa memikirkan potensi apa yang mereka miliki. Oleh karena itu, adanya ADF diharapkan mampu menampung segala aspirasi penyandang disabilitas dengan melakukan pengawalan, melakukan promosi, mengedukasi, dan mendampingi pemerintah dalam membuat rancangan ataupun program bagi penyandang disabilitas.

Dalam berita yang dikeluarkan oleh Kementerian Koordinator Bidang Pembangunan Manusia dan Kebudayaan, pada tahun 2015 lalu diadakan konferensi $A S E A N$ Disability Forum di Kuala Lumpur, Malaysia. Pertemuan tersebut membahas mengenai partisipasi disabilitas dalam kebijakan publik, demokratisasi, perdamaian, pembangunan, pelayanan publik, pemberdayaan kelompok, serta pemberdayaan di bidang ekonomi. Adanya ADF disambut baik oleh para penyandang disabilitas. Hal itu terlihat dari peran aktif para penyandang disabilitas yang menghadiri konferensi tersebut sekitar 300 orang penyandang disabilitas dari negara anggota ASEAN.

Dalam konferensi tersebut, menghasilkan beberapa rekomendasi yang nantinya akan menjadi pembahasan di ASEAN, yaitu mendorong negara anggota ASEAN untuk meratifikasi dan menerapkan konvensi PBB mengenai hak-hak disabilitas, memperlancar proses akreditasi Forum Disabilitas ASEAN dengan harapan mampu mempromosikan komunitas ASEAN yang meliputi semua jenis disabilitas, memajukan implementasi dekade ASEAN untuk disabilitas tahun 2011-2020, memastikan pemajuan pendekatan berbasis Hak Asasi Manusia bagi disabilitas, memastikan peran aktif disabilitas dalam 3 pilar Komunitas ASEAN, dan hal-hal lain mengenai kesejahteraan penyandang disabilitas.

Di Indonesia sendiri, terbentuknya ADF telah memberikan sedikit pengaruh terutama bagi kebijakan pemerintah. Salah satu bentuk implementasi dari pemerintah terhadap dukungannya dalam ADF yaitu mengamandemen UU terkait penyandang disabilitas di Indonesia yang menjadi dasar 
dari UU No.8 Tahun 2016 tentang Penyandang Disabilitas. Selain itu, pemerintah juga mulai mempersiapkan pemberdayaan bagi disabilitas yang menjadi harapan dari ADF untuk diterapkan diberbagai negara ASEAN (Mukhlisun, 2014). Dalam hal ini, pemerintah diminta untuk memberikan program pelatihan kerja, permodalan, serta yang terpenting adanya pendampingan dan pengawasan dari pemerintah.

Tidak hanya itu, saat ini ada beberapa perusahaan yang telah merekrut penyandang disabilitas menjadi pekerjanya, salah satunya perusahaan PT Omron Manufacturing Indonesia yang berlokasi di Cikarang, Jawa Barat. Hingga saat ini, PT Omron telah merekrut sekitar dua persen dari penyandang disabilitas (Warta, 2014 : 5). Pada bulan September tahun 2016 lalu, Menteri Sosial Indonesia juga melakukan pertemuan dengan negara anggota ASEAN dan tiga negara tambahan yaitu Korea, Jepang, dan China. Dalam pertemuan tersebut membahas pembangunan kesejahteraan sosial salah satunya bagi penyandang disabilitas. Pertemuan tersebut merupakan pertemuan kemitraan untuk memperkuat kerjasama negara menuju Visi Komunitas ASEAN 2025 (Mitrapol, 2016).

Melihat hal tersebut, maka dengan dibentuknya ADF membuat penyandang disabilitas menjadi salah satu isu besar yang harus diperhatikan oleh negara dalam hal perlidungan. Pemerintah saat ini mulai melakukan proses untuk memberikan hak bagi penyandang disabilitas agar mendapat penghidupan yang lebih baik. ADF sebagai forum baru juga terus berusaha untuk memaksimalkan posisinya demi tercapainya kesejahteraan para disabilitas di negara ASEAN salah satunya di Indonesia.

\section{Kesimpulan}

Menurut Undang-Undang Indonesia Nomor 8 Tahun 2016 tentang penyandang Disabilitas Pasal 1 menyatakan bahwa penyandang disabilitas adalah setiap orang yang mengalami keterbatasan fisik, intelektual, mental dan/atau sensorik dalam jangka waktu lama yang dalam berinteraksi dengan lingkungan dapat mengalami hambatan dan kesulitan untuk berpartisipasi secara penuh dan efektif dengan warga negara lainnya berdasarkan kesamaan hak. Penyandang disabilitas populasinya sekitar $15 \%$ dari seluruh penduduk didunia ini. Mereka dapat dikatakan sebagai kelompok minoritas yang terbesar di dunia.

Penyandang disabilitas banyak ditemukan di wilayah negara miskin dan berkembang. Banyak permasalahan yang mereka alami, mulai dari keterbatasan akses kesehatan, pendidikan, bahkan dalam akses ekonomi. Hal inilah yang menjadi salah satu penyebab banyaknya kemiskinan yang menimpa para penyandang disabilitas. PBB sebagai organisasi internasional bahkan telah melihat permasalahan penyandang disabilitas 
sebagai bentuk diskriminasi dan kejahatan kemanusiaan sehingga harus diperhatikan oleh pemerintah negara.

Indonesia menjadi salah sau negara yang belum mampu menangani masalah penyandang disabilitas. Walaupun telah adanya ratifikasi pemerintah Indonesia mengenai hak-hak penyandang disabilitas, namun hal itu tidak mampu menyelesaikan permasalahan mereka. Masih terbatasnya fasilitas publik, pendidikan, bahkan terbatasnya lapangan pekerjaan menjadi perhatian bagi pemerintah. Hal ini juga menjadi permasalahan serius di kancah ASEAN.

Terbentuknya ASEAN

Disability Forum menjadi salah satu perhatian pemimpin ASEAN dalam menangani permasalahan penyandang disabilitas. Forum ini dijadikan sebagai wadah bagi penyandang disabilitas untuk menyalurkan aspirasi mereka dalam penegakan hak dan keadilan mereka. Tidak hanya itu, ADF dimanfaatkan sebagai langkah untuk mempromosikan ASEAN Community 2015 agar para penyandang disabilitas ikutserta dalam penerapannya diberbagai negara.

Salah satu yang diharapkan adanya partisipasi aktif yaitu dalam bidang ekonomi. Melalui penerapan Masyarakat Ekonomi ASEAN, diharapkan para penyandang disabilitas mampu ikut serta demi membuka lahan pekerjaan bagi mereka. Melalui ADF, para penyandang disabilitas menginginkan adanya pelatihan kerja, terutama dalam berwirausaha agar kedepannya mampu menjadi masyarakat ekonomi yang mandiri. Keterbukaan lapangan pekerjaan juga menjadi salah satu hal penting yang diharapkan oleh penyandang disabilitas melalui Forum Disabilitas ASEAN. 


\section{Daftar Pustaka}

ADF (2017). “About ADF”. ASEAN Disability Forum. Diakses 12 Agustus 2017 pada http:// aseandisabilityforum.org/digaleri/

Adioetomo, Sri Moertiningsih, Daniel Mont, dan Irwanto. (n.d.) "Penyandang Disabilitas di Indonesia : Fakta Empiris dan Implikasi Untuk Kebijakan Perlindungan Sosial (Sebuah Laporan Penelitian)". Lembaga Demografi Fakultas Ekonomi-Universitas Indonesia bekerjasama dengan Tim Nasional Percepatan Penanggulangan Kemiskinan. TATTs dan USAID. Jakarta.

Betterwork (2013). Mempekerjakan Penyandang Disabilitas : Pedoman Untuk perusahaan. Betterwork. Jakarta : Better Work Indonesia. Diakses 12 Agustus 2017 pada http:// betterwork.org/indonesia/wp-content/uploads/20130201_employing-persons-withdisabilities-guideline indonesia final.pdf

Fachrudin, Fachri (2015). "Penyandang Disabilitas Indonesia Mencapai 9 Juta Jiwa", berita Okezone.com. Diakses 12 Agustus 2017 pada http://news.okezone.com/read/2015/12/03/337/1260124/penyandangdisabilitas-di-indonesia-mencapai-9-juta-jiwa

GPDLI (2017). “About-GPDLI". Gerakan Peduli Disabilitas dan Lepra Indonesia. Copyright 2017. Diakses 12 Agustus 2017 pada http://www.pedulidisabilitas.org/?page id=2

Harahap Repindowaty, Rahayu dan Bustanuddin. (2015). "Perlindungan Hukum Terhadap Penyandang Disabilitas menurut Convention on The Rights of Persons With Disabilities (CRPD)". Jurnal Inovatif. Volume VIII Nomor 1 Januari 2015

-Humas (2015). “Konferensi Forum Disabilitas ASEAN Tahun 2015 di Kuala Lumpur”. Berita 23 Oktober 2015. Kementerian Koordinator Bidang Pembangunan Manusia dan Kebudayaan. Diakses 12 Agustus 2017 pada http://www.kemenkopmk.go.id/artikel/konferensi-forumdisabilitas-asean-tahun-2015-di-kuala-lumpur

ILO (2013). Pedoman ILO tentang PENGELOLAAN PENYANDANG DISABILITAS DI TEMPAT KERJA. Edisi kedua 2013. Indonesia.

ILO (n.d.). "Inklusi Penyandang Disabilitas Indonesia". International Labor Organization. Diakses 27 November 2016 pada http://www.ilo.org.wcms 233426.pdf

Kemlu (2016). "Mewujudkan Masyarakat ASEAN yang Dinamis". Majalah Masyarakat ASEAN. Edisi 11 Tahun 2016. Direktorat Jenderal Kerja Sama ASEAN Kementerian Luar Negeri RI,Jakarta. Jakarta

Kurniawati, Dyah Estu (2012). "Pendekatan Intermestik Dalam Proses Perubahan Kebijakan: Sebuah Review Metodologis". Jurnal Studi Hubungan Internasional (JSHI) Vol 2 No 2 (2012). Diakses 12 Agustus 2017 pada http://ejournal.umm.ac.id/index.php/jshi/article/ view/1519/1623

Kusumaningrum, Demeiati Nur \& Dyah Estu Kurniawati (2016), "Intermesti Sebagai Pendekatan Dalam Studi Hubungan Internasional” dalam Intermestik Sebagai Pendekatan Dalam Studi Hubungan Internasional: Pengantar dan Contoh Penelitian. Leutika, Yogyakarta.

Mardenis. (2013). “Kontemplasi dan Analisis terhadap Klasifikasi dan Politik Hukum Penegakan 
HAM di Indonesia”. Jurnal RecthsVinding. Volume 2 Nomor 3, Desember 2013

Mitrapol (2016). “Terkait Anak, Penyandang Disabilitas dan Lanjut Usia Mensos RI Undang 10 Menteri ASEAN +3 Korea, Jepang, dan China”. Berita 2 Oktober 2016. Baladika Bhayangkara Digjaya. Diakses 12 Agustus 2017 pada http://www.mitrapol.com/2016/10/ terkait-anak-penyandang-disabilitas-dan.html?m=1

Mukhlisun. (2014). “ADF Minta Negara Asean Utamakan Pemberdayaan Disabilitas”. Berita 21 November 2014. Antara. Diakses 12 Agustus 2017 pada http://www.antarasumbar.com/ berita/124540/adf-minta-negara-asean-utamakan-pemberdayaan-disabilitas.html

Muljati, Wheny Hari. (2014). "Wirausaha Disabilitas Perlu Dukungan”. Berita 21 November 2014. Sinar Harapan. Diakses 12 Agustus 2017 pada http://www.sinarharapan.co/news/ $\underline{\mathrm{read} / 141121005 / \text { wirausaha-disabilitas-perlu-dukungan }}$

PPMI (2016). "Perlindungan Hukum dan Hak Bagi Penyandang Disabilitas Dalam Ketenagakerjaan". Berita 18 Oktober 2016. Persaudaraan Pekerja Muslim Indonesia. Diakses 12 Agustus 2017 pada http://www.ppmi -online.or.id/2016/10/perlindungan-hukum-dan-hak-bagi.html

Riyadi, Eko, dkk. (2012). "Vulnerable Groups: Kajian dan Mekanisme perlindungannya". Yogyakarta: Pusat Studi Hak Asasi Manusia Universitas Islam Indonesia

Rotinsulu A, Maulani. (2014). "Forum Disabilitas ADF”. Diakses dalam http:// www.perspektifbaru.com/wawancara/973 29 November 2016 pukul 19.41 WIB

Warta (2016). "SAMA : Ruang, Peluang, dan Perlakuan untuk Penyandang Disabilitas". Majalah Warta ILO. Edisi Dua Bahasa April 2016. ILO : Jakarta 